\title{
Response surface methodological optimization of L-asparaginase production from the medicinal plant endophyte Acinetobacter baumannii ZAS1
}

\author{
K. N. Abhini, Akhila B. Rajan, K. Fathimathu Zuhara and Denoj Sebastian * (1)
}

\begin{abstract}
Background: This study targets the enhanced production of L-asparaginase, an antitumor enzyme by Acinetobacter baumannii ZAS1. This organism is an endophyte isolated from the medicinal plant Annona muricata. Plackett-Burman design (PBD) and central composite design (CCD) were used for statistical optimization of media components.

Results: The organism exhibited 18.85 $\pm 0.2 \mathrm{U} / \mathrm{mL}$ enzyme activities in unoptimized media. Eight variables: L-asparagine, peptone, glucose, lactose, yeast extract, $\mathrm{NaCl}, \mathrm{MgSO}_{4}$, and $\mathrm{Na}_{2} \mathrm{HPO}_{4}$ were screened by PBD. Among them, only four factors - L-asparagine, peptone, glucose, and $\mathrm{Na}_{2} \mathrm{HPO}_{4}$ — were found to affect enzyme production significantly $(p<0.05)$. Furthermore, the best possible concentrations and interactive effects of the components that enhance this enzyme's output were chosen by using CCD on these selected variables. The results revealed that an optimized medium produces a higher concentration of enzymes than the unoptimized medium. After optimizing media components, the maximum L-asparaginase activity was $45.59 \pm 0.36 \mathrm{U} / \mathrm{mL}$, around the anticipated value of $45.04 \pm 0.42 \mathrm{U} /$ $\mathrm{mL}$. After optimization of process parameters, it showed a 2.41 -fold increase in the production of $\mathrm{L}$-asparaginase by the endophyte Acinetobacter baumannii ZAS1.

Conclusion: The findings of this study indicated that an endophyte, Acinetobacter baumannii ZAS1 that produces L-asparaginase could be used to increase enzyme output. However, using the statistical methods Plackett-Burman design and central composite design of response surface methodology is a handy tool for optimizing media components for increased L-asparaginase synthesis.
\end{abstract}

Keywords: Acinetobacter baumannii, Annona muricata, Central composite design, Endophyte, L-asparaginase, Response surface methodology

\section{Background}

L-asparaginase (EC 3.5.1.1) is an enzyme that belongs to the amidase group, which catalyzes the conversion of $\mathrm{L}$-asparagine into aspartic acid and ammonia [1]. The amino acid L-asparagine is essential for cell survival and is primarily involved in the synthesis of several essential

*Correspondence: drds@uoc.ac.in

Department of Life Sciences, University of Calicut, Malappuram, Kerala 673635, India proteins [2]. It is a non-essential amino acid that healthy cells can make with the help of the enzyme L-asparagine synthetase [3]. However, due to the insufficient expression of this particular enzyme in certain tumors, such as leukemic cells, they rely on the extracellular supply of this amino acid for their multiplication and survivability [3]. This suggests the importance of L-asparagine deprivation therapy for the selective elimination of tumor cells. $\mathrm{L}$-asparaginase is one of the drugs used in the treatment of acute lymphoblastic leukemia (ALL). 
The commercially available L-asparaginase is obtained from bacteria, mainly Escherichia coli and Erwinia chrysanthemi. This enzyme derived from Escherichia coli exhibits several side effects when used as a drug, including a high rate of hypersensitive reactions $[4,5]$. Hypersensitivity reactions can range from moderate allergic reactions to potentially lethal anaphylaxis [6]. In addition to this, several side effects like edema, serum sickness, bronchospasm, urticaria and rash, itching and swelling of extremities, and erythema also have been reported [7]. An enzyme derived from Erwinia chrysanthemi is successfully used to reduce hypersensitivity to $12-20 \%$, but this drug has a shorter half-life and lacks complete remission $[7,8]$. The essential prerequisites for developing a bio-better drug are obtaining an enzyme from a novel habitat and augmenting its production through process parameter optimization [9]. Many researchers are now using statistical methods to maximize L-asparaginase production by various microorganisms [10]. Increased $\mathrm{L}$-asparaginase production $(17.089 \mathrm{U} / \mathrm{mL})$ from halotolerant Bacillus licheniformis PPD37 was achieved by optimizing the process parameters through RSM [11]. Another study also reported improved L-asparaginase production from Pectobacterium carotovorum using $19.36 \mathrm{U} / \mathrm{mL}$ through RSM [12].

Recent research emphasizes the importance of this enzyme as an anticancer agent in various cancer cell lines [13]. This enzyme is also used in the food industry as an acrylamide-reducing agent in starchy food products. The diverse applications and growing needs have evoked scientists to search for efficient $\mathrm{L}$-asparaginase producers from new environments. Recently, the search for metabolites with desirable properties concentrates on organisms with novel biotopes [14]. These endophytes are microbes that grow within plant tissue symbiotically associated with such a biotope. Bioactive substances from endophytes are gaining attention due to their vast diversity, reduced toxicity, and ability to withstand different environmental conditions [15]. Though there have been several studies of L-asparaginase from various microbial sources, the production of this enzyme from medicinal plant endophytes has received less attention. In this context, we emphasize the need to study L-asparaginase from endophytes and improve its synthesis. Moreover, response surface methodology (RSM) is one of the statistical methods that have been successfully used to optimize the growth conditions of organisms to increase overall metabolite and biomass production [16, 17].

Acinetobacter baumannii ZAS1 is an endophyte obtained from the medicinal plant Annona muricata and thus expected to produce minimal side effects. This work aimed to optimize physical factors and media components for enhanced L-asparaginase synthesis from this organism. We employed the statistical method PlackettBurman design and response surface methodology's central composite design to accomplish this. The main objective of this work was to optimize L-asparaginase production using appropriate media components to produce this enzyme at a low cost. The Acinetobacter baumannii ZAS1 strain utilized in this investigation produced merely $18.85 \pm 0.2 \mathrm{U} / \mathrm{mL}$ of L-asparaginase in the unoptimized medium. As a result, statistical optimization of nutritional requirements is being investigated to boost L-asparaginase synthesis by this organism.

\section{Methods}

The process parameters of the endophyte Acinetobacter baumannii ZAS1 were optimized through the OFAT (one factor at a time) method as well as statistical methods like Plackett-Burman design (PBD) and central composite design (CCD) of RSM.

\section{Microbial strain}

The L-asparaginase producing bacterial endophyte Acinetobacter baumannii ZAS1 (Genbank Accession No. KX186685) [18], isolated from the medicinal plant Annona muricata (Accession No. CALI 7006), was used for the study. The organism was sub-cultured in nutrient agar (NA) medium every month and stored at $4{ }^{\circ} \mathrm{C}$.

\section{Chemicals}

L-asparagine used for the study was purchased from Sisco Research Laboratories Pvt Ltd (SRL). Other chemicals (analytical grade) used were obtained from different commercial sources.

\section{Media}

Acinetobacter baumannii ZAS1 cultures were grown in unoptimized M9 medium [19], which contained the following components: L-asparagine $(10 \mathrm{~g} / \mathrm{l}), \mathrm{KH}_{2} \mathrm{PO}_{4}$ $(3 \mathrm{~g} / \mathrm{l}), \quad \mathrm{Na}_{2} \mathrm{HPO}_{4}(6 \mathrm{~g} / \mathrm{l}), \quad \mathrm{NaCl}(0.5 \mathrm{~g} / \mathrm{l}), \quad \mathrm{CaCl}_{2} \cdot 2 \mathrm{H}_{2} \mathrm{O}$ $(0.001 \mathrm{~g} / \mathrm{l}), \mathrm{MgSO}_{4} \cdot 7 \mathrm{H}_{2} \mathrm{O}(0.12 \mathrm{~g} / \mathrm{l})$, and agar $(20 \mathrm{~g} / \mathrm{l})$. The $\mathrm{pH}$ of the medium was 7.0, and the incubation temperature was set as $37^{\circ} \mathrm{C}$.

\section{Extracellular L-asparaginase production and extraction}

The bacterial culture used as primary inoculum was grown overnight in $10 \mathrm{ml}$ of $\mathrm{M} 9$ medium at $37^{\circ} \mathrm{C}$ in an incubator (shaking). In $50 \mathrm{ml}$ of $\mathrm{M} 9$ broth medium, $1 \%$ of the overnight grown culture (adjusted to a McFarland standard of 0.5) was used as an inoculum to produce L-asparaginase. Following incubation, the culture was centrifuged at $10,000 \times g$ for $10 \mathrm{~min}$ at $4{ }^{\circ} \mathrm{C}$, and the supernatant was used to determine the enzyme activity. 


\section{L-asparaginase assay}

The Nesslerization reaction [20] is a commonly used method for the determination of L-asparaginase activity. The amount of ammonia liberated was determined in this reaction. At $37^{\circ} \mathrm{C}$, one unit of L-asparaginase activity corresponds to the amount of enzyme required to liberate $1 \mu \mathrm{mol}$ of ammonia per minute.

\section{Optimization of physical parameters through OFAT method}

The OFAT method was used to optimize the temperature, $\mathrm{pH}$, and agitation speed for L-asparaginase production. For optimizing temperature, the unoptimized medium was seeded with inoculum and incubated in a shaking incubator at varying temperatures $\left(27^{\circ} \mathrm{C}, 32{ }^{\circ} \mathrm{C}\right.$, $37^{\circ} \mathrm{C}, 42^{\circ} \mathrm{C}$, and $47^{\circ} \mathrm{C}$ ). The culture was centrifuged after $24 \mathrm{~h}$ of incubation, and the cell-free supernatant was used as a crude enzyme for the L-asparaginase assay. For optimizing $\mathrm{pH}$, the unoptimized medium with varying $\mathrm{pH}(6$, $7,8,9$, and 10) was seeded with inoculum and incubated in a shaking incubator at an optimized temperature. The appropriate agitation speed for the best production of the enzyme was discovered by inoculating the medium (adjusted to optimized $\mathrm{pH}$ ) and incubating at various agitation speeds $(50,100,150$, and 200$)$ under optimized temperature. The L-asparaginase assay was performed in duplicates with crude enzyme produced from a 24-h culture.

\section{Selection of carbon-nitrogen and mineral sources through OFAT method}

For selecting the best sources of carbon, nitrogen, and ion, the unoptimized M9 medium was supplemented with one of the carbon (sucrose, lactose, maltose, glucose, fructose, and galactose), nitrogen (peptone, beef extract, yeast extract, malt extract, ammonium chloride, and sodium nitrate), or mineral $\left(\mathrm{NaCl}, \mathrm{KCl}, \mathrm{Na}_{2} \mathrm{HPO}_{4}\right.$, $\left.\mathrm{KH}_{2} \mathrm{PO}_{4}, \mathrm{MgSO}_{4}\right)$ sources. It was inoculated with primary culture and incubated under optimized physical conditions.

\section{Screening of important variables through PBD}

Different carbon, nitrogen, and mineral sources were screened using a statistical method called PBD [21]. The statistical software package MINITAB (Release 16, PA, USA) was used to design the experiments under PBD. Eight variables were considered in this study. Among these variables, one is L-asparagine, which is an inducer for the production of the enzyme. The remaining seven variables were sources of carbon, nitrogen, and ions obtained by preliminary screening of different variables through the OFAT method. Table 1 shows the
Table 1 Variables and their codes used in Plackett-Burman design

\begin{tabular}{|c|c|c|c|}
\hline Code & Nutrients (g/l) & $\operatorname{Low}(-1)$ & High $(+1)$ \\
\hline A & L-asparagine & 2.5 & 12.5 \\
\hline B & Peptone & 1 & 5 \\
\hline$C$ & Glucose & 0.2 & 1 \\
\hline $\mathrm{D}$ & Lactose & 0.2 & 1 \\
\hline$E$ & Yeast extract & 1 & 5 \\
\hline $\mathrm{F}$ & $\mathrm{NaCl}$ & 0.5 & 2.5 \\
\hline G & $\mathrm{MgSO}_{4}$ & 0.5 & 2.5 \\
\hline $\mathrm{H}$ & $\mathrm{Na}_{2} \mathrm{HPO}_{4}$ & 0.5 & 2.5 \\
\hline
\end{tabular}

experimental model for the selection of different variables. Each variable was investigated at its low level $(-1)$ and high level $(+1)$.

This PBD is based on the first-order model;

$$
Y=\beta_{0}+\Sigma \beta_{i} x_{i}(i=1, \ldots, k)
$$

where $Y$ is L-asparaginase activity (the response), $\beta_{0}$ is the model intercept, $\beta_{\mathrm{i}}$ is the linear coefficient, and $x_{\mathrm{i}}$ is the level of an independent variable.

The eight variables selected for the experiment were L-asparagine, peptone, glucose, lactose, yeast extract, $\mathrm{NaCl}, \mathrm{MgSO}_{4}$, and $\mathrm{Na}_{2} \mathrm{HPO}_{4}$. The statistical tool designed 20 experimental runs to screen those variables. The tests were conducted in duplicate, and the calculations were based on the average enzyme activity (Table 2). Based on this, variables with confidence levels equal to or greater than $95 \%$ were thought to impact L-asparaginase production significantly.

\section{Optimization of critical medium components using CCD}

Variables selected through PBD were subjected to CCD as it comprises duplication of the central point. The CCD containing four variables at its five coded levels $(-\alpha,-1$, $0,+1$ and $+\alpha)$ were generated using the statistical software package "Design Expert $7^{\circledR}$ (Stat-Ease Inc., USA) (Table 3). A total of 30 experimental runs were created (Table 4), in which 24 runs were the blend of actual levels of the study parameters, and the remaining six runs were the replication of medial points. Experimental runs performed at the medial points were to build the curvature and balance the lack of fit values, which describes the significance of the model [22]. CCD based designs are widely used for the production optimization of many industrial enzymes [23, 24]. The experiments were conducted in duplicates and the average L-asparaginase enzyme activity was used to calculate the response.

Analysis of variance (ANOVA) of data was performed. The response surface regression procedure was used to 
Table 2 Experimental design and results of PBD

\begin{tabular}{|c|c|c|c|c|c|c|c|c|c|}
\hline Run order & L-asparagine & Peptone & Glucose & Lactose & Yeast extract & $\mathrm{NaCl}$ & $\mathrm{MgSO}_{4}$ & $\mathrm{NA}_{2} \mathrm{HPO}_{4}$ & $\begin{array}{l}\text { L-asparaginase } \\
\text { activity } \mathrm{U} / \mathrm{mL} \text { ) }\end{array}$ \\
\hline 1 & -1 & 1 & 1 & -1 & 1 & 1 & -1 & -1 & $6.13 \pm 0.43$ \\
\hline 2 & 1 & 1 & -1 & -1 & -1 & -1 & 1 & -1 & $17.18 \pm 0.21$ \\
\hline 3 & -1 & -1 & -1 & -1 & -1 & -1 & -1 & -1 & $1.59 \pm 0.34$ \\
\hline 4 & -1 & -1 & 1 & 1 & -1 & 1 & 1 & -1 & $2.22 \pm 0.29$ \\
\hline 5 & 1 & -1 & -1 & 1 & 1 & -1 & 1 & 1 & $16.88 \pm 0.61$ \\
\hline 6 & 1 & 1 & -1 & 1 & 1 & -1 & -1 & -1 & $16.22 \pm 0.48$ \\
\hline 7 & -1 & -1 & -1 & -1 & 1 & -1 & 1 & -1 & $2.34 \pm 0.37$ \\
\hline 8 & -1 & 1 & -1 & 1 & 1 & 1 & 1 & -1 & $5.59 \pm 0.25$ \\
\hline 9 & 1 & 1 & 1 & -1 & -1 & 1 & 1 & -1 & $16.06 \pm 0.47$ \\
\hline 10 & 1 & -1 & 1 & -1 & 1 & 1 & 1 & 1 & $17.68 \pm 0.26$ \\
\hline 11 & -1 & 1 & 1 & -1 & -1 & -1 & -1 & 1 & $7.93 \pm 0.34$ \\
\hline 12 & 1 & 1 & 1 & 1 & -1 & -1 & 1 & 1 & $22.34 \pm 0.51$ \\
\hline 13 & 1 & -1 & -1 & -1 & -1 & 1 & -1 & 1 & $16.61 \pm 0.36$ \\
\hline 14 & -1 & 1 & 1 & 1 & 1 & -1 & -1 & 1 & $10.59 \pm 0.42$ \\
\hline 15 & 1 & 1 & -1 & -1 & 1 & 1 & -1 & 1 & $16.84 \pm 0.33$ \\
\hline 16 & -1 & -1 & 1 & -1 & 1 & -1 & 1 & 1 & $11.5 \pm 0.28$ \\
\hline 17 & 1 & -1 & 1 & 1 & -1 & -1 & -1 & -1 & $15.61 \pm 0.43$ \\
\hline 18 & -1 & -1 & -1 & 1 & -1 & 1 & -1 & 1 & $2.38 \pm 0.31$ \\
\hline 19 & -1 & 1 & -1 & 1 & -1 & 1 & 1 & 1 & $9.97 \pm 0.51$ \\
\hline 20 & 1 & -1 & 1 & 1 & 1 & 1 & -1 & -1 & $18.59 \pm 0.60$ \\
\hline
\end{tabular}

Table 3 Experimental range and levels of independent variables used for CCD

\begin{tabular}{lllllll}
\hline Variables & Components & $\mathbf{- a}$ & $\mathbf{- 1}$ & $\mathbf{0}$ & $+\mathbf{1}$ \\
\hline A & L-asparagine & 0 & 5 & 10 & 15 & $+\mathbf{a}$ \\
B & Peptone & 1 & 3 & 5 & 7 & 20 \\
C & Glucose & 0 & 4 & 6 & 1.5 & 8 \\
D & $\mathrm{Na}_{2} \mathrm{HPO}_{4}$ & 2 & 4 & 10 \\
\hline
\end{tabular}

fit the experimental results by the second-order polynomial equation:

$$
\begin{gathered}
\mathrm{Y}=\beta_{0}+\beta_{1} \mathrm{~A}+\beta_{2} \mathrm{~B}+\beta_{3} \mathrm{C}+\beta_{4} \mathrm{D}+\beta_{11} \mathrm{~A}^{2}+\beta_{22} \mathrm{~B}^{2}+\beta_{33} \mathrm{C}^{2}+ \\
\beta_{44} \mathrm{D}^{2}+\beta_{12} \mathrm{AB}+\beta_{13} \mathrm{AC}+\beta_{14} \mathrm{AD}+\beta_{23} \mathrm{BC}+\beta_{24} \mathrm{BD}+\beta_{34} \mathrm{CD}
\end{gathered}
$$

where $Y$ is the predicted L-asparaginase activity (response), $A, B, C$, and $D$ are the independent variables studied, $\beta_{0}$ is intercept, $\beta_{1}, \beta_{2}, \beta_{3}$, and $\beta_{4}$ are linear coefficients, $\beta_{11}, \beta_{22}, \beta_{33}, \beta_{44}$ are squared coefficients, and $\beta_{12}$, $\beta_{13}, \beta_{14}, \beta_{23}, \beta_{24}$, and $\beta_{34}$ are interaction coefficients.

\section{Validation of the model}

Experiments were conducted to validate the statistical model at its optimal levels of the most significant variables under a predicted set of conditions.

\section{Analysis of the growth curve}

A growth curve analysis was performed to examine the correlation between bacterial growth and L-asparaginase production in the optimized medium. Bacterial growth was monitored using an optical density (OD) at $600 \mathrm{~nm}$, and activity was recorded in $\mathrm{U} / \mathrm{mL}$ every $2 \mathrm{~h}$.

\section{Results}

Extracellular L-asparaginase production

According to quantitative analysis using the Nesslerization reaction, the organism Acinetobacter baumannii ZAS1 had $18.85 \pm 0.2 \mathrm{U} / \mathrm{mL}$ enzyme activities in unoptimized media. The high value obtained indicated the release of the maximal quantity of ammonia after the catalytic activity of L-asparaginase on the substrate L-asparagine. 
Table 4 CCD of selected variables with the experimental and predicted response

\begin{tabular}{|c|c|c|c|c|c|c|c|c|c|c|c|}
\hline \multirow[t]{2}{*}{ Run } & \multicolumn{2}{|c|}{ A: L-asparagine } & \multicolumn{2}{|c|}{ B: peptone } & \multicolumn{2}{|c|}{ C: glucose } & \multicolumn{2}{|c|}{ D: $\mathrm{Na}_{2} \mathrm{HPO}_{4}$} & \multicolumn{2}{|c|}{$\begin{array}{l}\text { L-asparaginase activity (U/ } \\
\mathrm{mL})\end{array}$} & \multirow[t]{2}{*}{ Residuals } \\
\hline & Coded & Actual & Coded & Actual & Coded & Actual & Coded & Actual & Observed & Predicted & \\
\hline 1 & 0 & 10 & 0 & 5 & 0 & 1 & 0 & 6 & 40.3819 & 42.7545 & -2.37 \\
\hline 2 & -1 & 5 & +1 & 7 & +1 & 1.5 & +1 & 8 & 29.2708 & 29.7992 & -0.53 \\
\hline 3 & -1 & 5 & +1 & 7 & -1 & 0.5 & +1 & 8 & 24.7569 & 24.6849 & 0.07 \\
\hline 4 & $+a$ & 20 & 0 & 5 & 0 & 1 & 0 & 6 & 44.2014 & 43.2235 & 0.98 \\
\hline 5 & -1 & 5 & -1 & 3 & +1 & 1.5 & +1 & 8 & 23.7153 & 23.0642 & 0.65 \\
\hline 6 & 0 & 10 & 0 & 5 & $+a$ & 2 & 0 & 6 & 32.3958 & 31.911 & 0.48 \\
\hline 7 & 0 & 10 & 0 & 5 & 0 & 1 & 0 & 6 & 43.1597 & 42.7545 & 0.41 \\
\hline 8 & +1 & 15 & -1 & 3 & +1 & 1.5 & +1 & 8 & 38.9931 & 39.7518 & -0.76 \\
\hline 9 & +1 & 15 & -1 & 3 & -1 & 0.5 & -1 & 4 & 28.2292 & 28.2645 & -0.04 \\
\hline 10 & 0 & 10 & 0 & 5 & 0 & 1 & $-a$ & 2 & 21.2847 & 22.3334 & -1.05 \\
\hline 11 & 0 & 10 & 0 & 5 & 0 & 1 & 0 & 6 & 42.8125 & 42.7545 & 0.06 \\
\hline 12 & +1 & 15 & -1 & 3 & -1 & 0.5 & +1 & 8 & 37.6042 & 37.5889 & 0.02 \\
\hline 13 & 0 & 10 & 0 & 5 & 0 & 1 & $+a$ & 10 & 37.2569 & 36.2513 & 1.01 \\
\hline 14 & +1 & 15 & +1 & 7 & -1 & 0.5 & -1 & 4 & 28.75 & 28.793 & -0.04 \\
\hline 15 & -1 & 5 & -1 & 3 & -1 & 0.5 & +1 & 8 & 19.5486 & 19.7294 & -0.18 \\
\hline 16 & -1 & 5 & +1 & 7 & -1 & 0.5 & -1 & 4 & 16.4236 & 16.2285 & 0.20 \\
\hline 17 & -1 & 5 & +1 & 7 & +1 & 1.5 & -1 & 4 & 25.7986 & 25.2057 & 0.59 \\
\hline 18 & +1 & 15 & +1 & 7 & +1 & 1.5 & +1 & 8 & 40.3819 & 41.2351 & -0.85 \\
\hline 19 & -1 & 5 & -1 & 3 & -1 & 0.5 & -1 & 4 & 11.9097 & 10.4484 & 1.46 \\
\hline 20 & 0 & 10 & 0 & 5 & 0 & 1 & 0 & 6 & 44.2014 & 42.7545 & 1.45 \\
\hline 21 & 0 & 10 & 0 & 5 & 0 & 1 & 0 & 6 & 42.8125 & 42.7545 & 0.06 \\
\hline 22 & 0 & 10 & 0 & 5 & 0 & 1 & 0 & 6 & 43.1597 & 42.7545 & 0.41 \\
\hline 23 & $-a$ & 0 & 0 & 5 & 0 & 1 & 0 & 6 & 12.9514 & 13.9715 & -1.02 \\
\hline 24 & +1 & 15 & -1 & 3 & +1 & 1.5 & -1 & 4 & 34.8264 & 34.2902 & 0.54 \\
\hline 25 & +1 & 15 & +1 & 7 & +1 & 1.5 & -1 & 4 & 36.2153 & 36.5982 & -0.38 \\
\hline 26 & 0 & 10 & 0 & 5 & $-a$ & 0 & 0 & 6 & 20.2431 & 20.771 & -0.53 \\
\hline 27 & -1 & 5 & -1 & 3 & +1 & 1.5 & -1 & 4 & 17.4653 & 17.6461 & -0.18 \\
\hline 28 & 0 & 10 & $-a$ & 1 & 0 & 1 & 0 & 6 & 24.0625 & 24.7927 & -0.73 \\
\hline 29 & 0 & 10 & $+a$ & 9 & 0 & 1 & 0 & 6 & 32.7431 & 32.0561 & 0.69 \\
\hline 30 & +1 & 15 & +1 & 7 & -1 & 0.5 & +1 & 8 & 36.9097 & 37.2927 & -0.38 \\
\hline
\end{tabular}

\section{Optimization of physical parameters for L-asparaginase production}

The physical factors like temperature, $\mathrm{pH}$, and agitation speed that influence L-asparaginase production were optimized by the OFAT method. The results are depicted in Fig. 1. In the case of the temperature study, the endophyte Acinetobacter baumannii ZAS1 showed excellent activity $(18.854 \pm 0.2 \mathrm{U} / \mathrm{mL})$ at $37{ }^{\circ} \mathrm{C}$; this activity was sustained until $42{ }^{\circ} \mathrm{C}$ and declined with a further hike in temperature. The optimum $\mathrm{pH}$ required for the augmented production $(19.201 \pm 0.2 \mathrm{U} / \mathrm{mL})$ of L-asparaginase by this organism was $\mathrm{pH} 7$. The $\mathrm{pH}$ above and below this point showed decreased activity. Furthermore, the optimum agitation speed required for the maximum production of L-asparaginase enzyme $(18.854 \pm 0.6 \mathrm{U} / \mathrm{mL})$ by Acinetobacter baumannii ZAS1 was $150 \mathrm{rpm}$. In contrast, the production was lower at speeds above and below this, i.e., at $100 \mathrm{rpm}$ and $200 \mathrm{rpm}$.

\section{Primary screening of carbon, nitrogen, and ion sources}

The result of the primary screening experiment is shown in Fig. 2. According to the experimental results, glucose and lactose were promising carbon sources for L-asparaginase production among the different carbon sources evaluated (Fig. 2a). Over the various nitrogen sources tested, peptone and yeast extract expressed increased enzyme activity (Fig. 2b). $\mathrm{NaCl}, \mathrm{Na}_{2} \mathrm{HPO}_{4}$, and $\mathrm{MgSO}_{4}$ showed considerable improvement in the enzyme production from the diverse sources of ions tested (Fig. 2c). According to the findings, the production of L-asparaginase by Acinetobacter baumannii ZAS1 improves when 

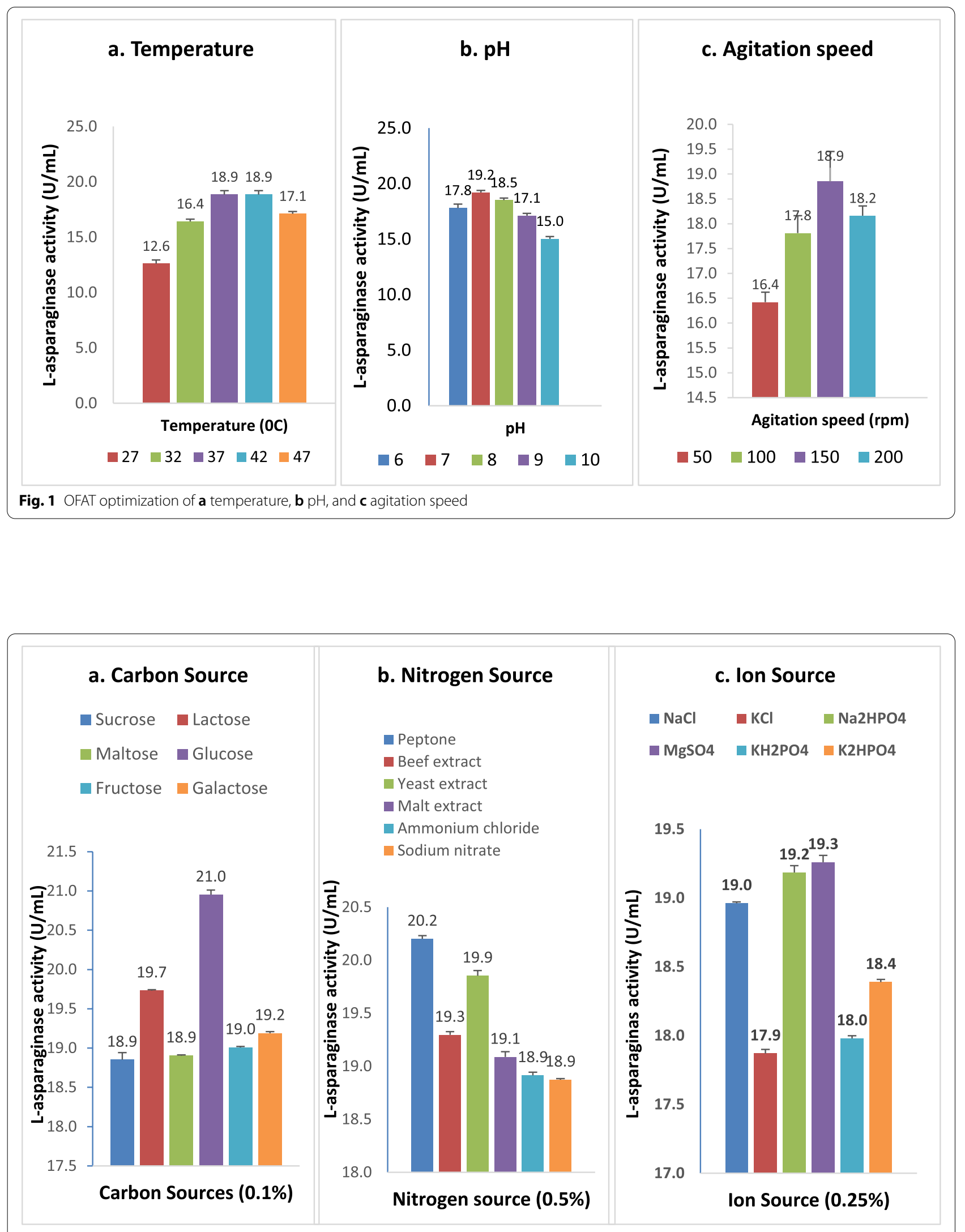

Fig. 2 OFAT optimization of a carbon, $\mathbf{b}$ nitrogen, and $\mathbf{c}$ ion sources supplementing M9 media 
different carbon, nitrogen, and ion sources are used in the media.

\section{Screening of most significant variables through PBD}

PBD was applied in this study to determine the main media components influencing L-asparaginase production. The L-asparagine, peptone, glucose, and $\mathrm{Na}_{2} \mathrm{HPO}_{4}$ were found to have a major impact on L-asparaginase synthesis by Acinetobacter baumannii ZAS1. The complete experimental design, including response values, is provided in Tables 2 and 5. The selected variable, L-asparagine ( $p$-value 0$)$, significantly affects the production of $\mathrm{L}$-asparaginase. The second variable selected through the PBD experiment was peptone ( $p$-value $0.025)$ as an additional nitrogen source in the enhanced production of L-asparaginase. The third variable chosen by the PBD experiment was glucose ( $p$-value 0.027 ), which acts as a carbon source for the better production of this enzyme. Through this experiment, the ion source $\mathrm{Na}_{2} \mathrm{HPO}_{4}$ ( $p$-value 0.005) also showed a significant effect on L-asparaginase production. The results revealed that additional nitrogen, carbon, and ion sources contributed significantly to the highest production of this enzyme.

\section{Optimization of important medium components using CCD}

In this CCD experiment, the various substances chosen through PBD studies, namely L-asparagine, peptone, glucose, and $\mathrm{Na}_{2} \mathrm{HPO}_{4}$, were treated as four independent variables on which responses were calculated. A total of 30 experimental runs were performed using these four variables. The entire experimental plan, including response values, is described in Table 4.

\section{Regression analysis}

Appropriate conditions for maximum L-asparaginase activity were established using regression analysis. A second-order polynomial equation representing the relationship between enzyme activity, L-asparagine, peptone, glucose, and $\mathrm{Na}_{2} \mathrm{HPO}_{4}$ was generated using multiple regression analyses.

The second-order polynomial equation calculated the predicted L-asparaginase activity is as follows:

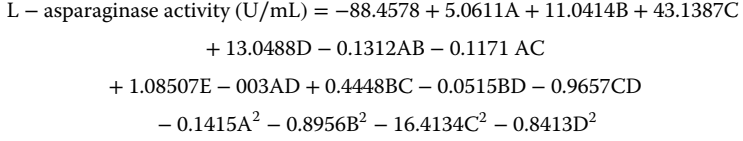

where $A, B, C$, and $D$ are concentrations of L-asparagine, peptone, glucose and $\mathrm{Na}_{2} \mathrm{HPO}_{4}$, respectively. The $F$ test was assessed the statistical significance of the secondorder polynomial equation and the results of ANOVA are given in Table 6.

According to the ANOVA analysis, the model $p$-value was 0.0001 , which is less than 0.05 , indicating that the model terms are significant. In this case, $A, B, C, D, A B$, $C D, A^{2}, B^{2}, C^{2}$, and $D^{2}$ are all-important model terms. The lack of fit $p$-value of 0.7239 indicates that the lack of fit is insignificant in proportion to the pure error. A nonsignificant lack of fit is good. The "predicted R-squared value" of 0.9748 agrees with the "adjusted R-squared value" of 0.9876. "Adequate precision" measures the signal-to-noise ratio. A ratio greater than 4 is desirable. Here, the value of 41.326 indicates an adequate signal. Thus, the model could be used to navigate the design space.

\section{Interaction among variables}

The effects of variable interactions on $\mathrm{L}$-asparaginase activity were investigated. Optimized 3D surface plots were used to depict the interactive effects of any two factors. In this plot, two variables were kept constant while the other one was present in the investigation range. The level of each variable influencing the maximum yield of L-asparaginase was analyzed. The $3 \mathrm{D}$ response

Table 5 Statistical analysis of PBD of eight variables

\begin{tabular}{|c|c|c|c|c|c|c|c|}
\hline Term & Effect & Coef & SE coef & $T$-value & $F$-value & $p$-value & $\begin{array}{l}\text { Confidence } \\
\text { level }(\%)\end{array}$ \\
\hline L-asparagine & 11.377 & 5.689 & 0.452 & 12.57 & 158.04 & 0.000 & $100^{\mathrm{a}}$ \\
\hline Peptone & 2.345 & 1.172 & 0.452 & 2.59 & 6.71 & 0.025 & $97.5^{\mathrm{a}}$ \\
\hline Glucose & 2.305 & 1.152 & 0.452 & 2.55 & 6.49 & 0.027 & $97.3^{a}$ \\
\hline Lactose & 0.653 & 0.327 & 0.452 & 0.72 & 0.52 & 0.486 & 51.4 \\
\hline yeast extract & 1.047 & 0.524 & 0.452 & 1.16 & 1.34 & 0.272 & 72.8 \\
\hline $\mathrm{NaCl}$ & -1.011 & -0.505 & 0.452 & -1.12 & 1.25 & 0.288 & 71.2 \\
\hline $\mathrm{MgSO} 4$ & 0.927 & 0.464 & 0.452 & 1.02 & 1.05 & 0.328 & 67.2 \\
\hline $\mathrm{Na}_{2} \mathrm{HPO}_{4}$ & 3.119 & 1.56 & 0.452 & 3.45 & 11.88 & 0.005 & $99.5^{\mathrm{a}}$ \\
\hline $\mathrm{R}^{2}$ & 0.9445 & $\operatorname{Adj} R^{2}$ & 0.9042 & Pred $R^{2}$ & 0.8166 & & \\
\hline
\end{tabular}

a Statistically significant at $95 \%$ confidence level 
Table 6 Analysis of variance (ANOVA) of response surface quadratic model for the production of L-asparaginase

\begin{tabular}{llllll}
\hline Source & Sum of squares & df & Mean square & $\boldsymbol{F}$ value & $\boldsymbol{p}$ value prob $>\boldsymbol{f}$ \\
\hline Model & 2918.75 & 14 & 208.48 & 165.72 & $<0.0001^{*}$ \\
A-L-asparagine & 1283.65 & 1 & 1283.65 & 1020.3 & $<0.0001^{*}$ \\
B-Peptone & 79.12 & 1 & 79.12 & 62.89 & $<0.0001^{*}$ \\
C-Glucose & 186.15 & 1 & 186.15 & 147.97 & $<0.0001^{*}$ \\
D- $\mathrm{Na}_{2} \mathrm{HPO}_{4}$ & 290.56 & 1 & 290.56 & 230.96 & $<0.0001^{*}$ \\
$\mathrm{AB}$ & 27.58 & 1 & 27.58 & 21.92 & $0.0003^{*}$ \\
$\mathrm{AC}$ & 1.37 & 1 & 1.37 & 1.09 & 0.3127 \\
$\mathrm{AD}$ & $1.884 \mathrm{E}-0.003$ & 1 & $1.884 \mathrm{E}-0.003$ & $1.497 \mathrm{E}-0.003$ & 0.9696 \\
$\mathrm{BC}$ & 37.1 & 1 & 3.17 & 2.52 & 0.1335 \\
$\mathrm{BD}$ & 0.68 & 1 & 0.68 & 0.54 & 0.4735 \\
CD & 14.92 & 1 & 14.92 & 11.86 & $0.0036^{*}$ \\
A2 & 343.56 & 1 & 343.56 & 273.09 & $<0.0001^{*}$ \\
B2 & 352.03 & 1 & 352.03 & 279.83 & $<0.0001^{*}$ \\
C2 & 461.83 & 1 & 461.83 & 367.1 & $<0.0001^{*}$ \\
D2 & 310.68 & 1 & 310.68 & 246.95 & $<0.0001^{*}$ \\
Residual & 18.87 & 15 & 1.26 & & \\
Lack of fit & 10.81 & 10 & 1.08 & 0.67 & \\
Pure error & 8.06 & 5 & 1.61 & & \\
Cor total & 2937.63 & 29 & & & \\
\hline
\end{tabular}

*Statistically significant at 95\% confidence level ( $p$ value $<0.05$ )

plot shown in Fig. 3a depicts the interaction between $\mathrm{L}$-asparagine and peptone. The L-asparaginase activity increases with the increasing concentration of L-asparagine; the activity starts to decline only towards its maximum concentration. In the case of peptone, the enzyme activity is highest at its intermediate value and begins to decline after that. This plot showed a strong interaction between variables as indicated by $p<0.05$. Figure $3 \mathrm{~b}$ shows the interaction between $\mathrm{L}$-asparagine and glucose. In this case, enzyme activity increases with a higher concentration of $\mathrm{L}$-asparagine and starts declining at its maximal point. As the glucose concentration increases, the enzyme activity also increases up to its median value and starts declining beyond that. Because the $p$-value is so high, there was no interaction between these two factors. Figure $3 \mathrm{c}$ explains the interaction between L-asparagine and $\mathrm{Na}_{2} \mathrm{HPO}_{4}$. Here, enzyme activity increases as $\mathrm{L}$-asparagine and $\mathrm{Na}_{2} \mathrm{HPO}_{4}$ concentrations increase, and it starts declining only at its maximum value. There was no evidence of an interaction effect between these variables. Figure $3 \mathrm{~d}$ describes the interaction between peptone and glucose. According to the graph, the enzyme activity is highest when the concentrations of peptone and glucose are at their midpoints; activity declines beyond this point as the concentrations of variables increase. There was no interactive effect among these variables.

Figure $3 \mathrm{e}$ shows the interaction between peptone and $\mathrm{Na}_{2} \mathrm{HPO}_{4}$. The enzyme activity becomes maximum when peptone reaches its middle value, whereas in the case of $\mathrm{Na}_{2} \mathrm{HPO}_{4}$, the enzyme activity starts declining towards its end value. In this case, also we could not see any interaction among these variables. Figure $3 \mathrm{f}$ depicts the interaction between glucose and $\mathrm{Na}_{2} \mathrm{HPO}_{4}$. Enzyme activity increases as the glucose concentration reach its middle value and start declining beyond that. In the case of $\mathrm{Na}_{2} \mathrm{HPO}_{4}$, enzyme activity rises beyond the middle value and begins to decline only when it approaches its maximum value. This graph also showed the strong interaction between variables as indicated by $p<0.05$.

\section{Validation of the model}

To verify the adequacy of statistical analysis, some experiments were suggested by the software and were carried out in duplicates (Table 7). The maximum L-asparaginase activity predicted by the experimental design using the optimum concentrations of selected components $(11.50 \mathrm{~g} / \mathrm{l} \mathrm{L}$-asparagine, $5.30 \mathrm{~g} / \mathrm{l}$ peptone, $1.32 \mathrm{~g} / \mathrm{l}$ glucose, and $7.54 \mathrm{~g} / \mathrm{l} \mathrm{Na}_{2} \mathrm{HPO}_{4}$ ) was $45.04 \pm 0.42 \mathrm{U} / \mathrm{mL}$, and this value was in agreement with the experimental yield of $45.59 \pm 0.36 \mathrm{U} / \mathrm{mL}$. This experimental result verifies the validity of the model and the existence of optimal points.

\section{Analysis of growth curve}

A result of the growth curve analysis is depicted in Fig. 4. The organism showed maximum L-asparaginase activity 

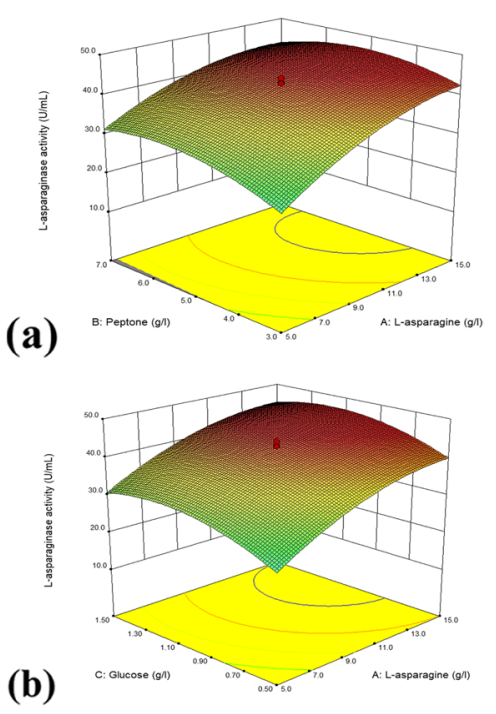

(b)
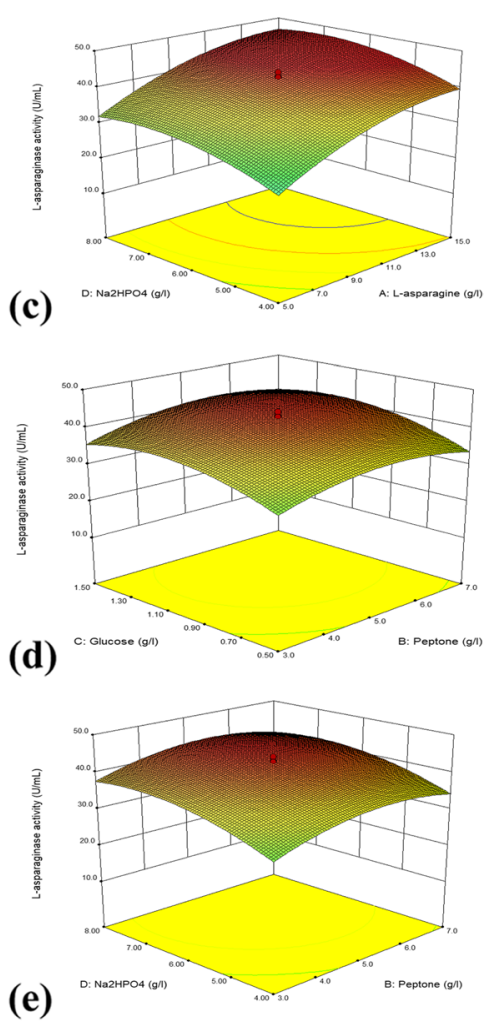

(e)

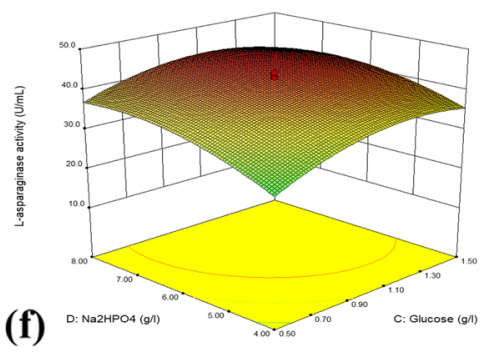

Fig 3 Response surface plot showing the interaction between variables $\mathbf{a}$ peptone and L-asparagine, $\mathbf{b}$ glucose and L-asparagine, $\mathbf{c}$ $\mathrm{Na}_{2} \mathrm{HPO}_{4}$ and L-asparagine, $\mathbf{d}$ glucose and peptone, e peptone and $\mathrm{Na}_{2} \mathrm{HPO}_{4}$, and $\mathbf{f}$ glucose and $\mathrm{Na}_{2} \mathrm{HPO}_{4}$

$(45.52 \pm 0.23 \mathrm{U} / \mathrm{mL})$ at $24 \mathrm{~h}$ of incubation. The organism revealed a maximum growth rate after $24 \mathrm{~h}$.

\section{Discussion}

Recent developments have heightened the need to find better sources of the L-asparaginase enzyme. The endophyte Acinetobacter baumannii ZAS1 showed promising L-asparaginase activity. Many scholars have discussed the differences in $\mathrm{L}$-asparaginase production between microorganisms from different habitats, and the impact of cultural conditions on the amount of L-asparaginase generated [11, 12]. The physical factors and the culture media composition considerably influence the cell growth and production of metabolites [25]. The present study was performed to improve the enzyme production by this endophyte by optimizing the physical conditions and media components using response surface methodology.

Temperature is an important factor in the success of fermentation reactions. It controls the growth and production of metabolites by microorganisms and varies from one organism to another [26]. The temperature modulates extracellular enzyme synthesis by altering the physical properties of the cell membrane [27]. In the case of Acinetobacter baumannii ZAS1, the maximum L-asparaginase $(18.854 \pm 0.2 \mathrm{U} / \mathrm{mL})$ production was observed at $37{ }^{\circ} \mathrm{C}$, and the enzyme production was found to be sustained up to $42{ }^{\circ} \mathrm{C}$. A gradual decline of enzyme activity was observed beyond this temperature range. The ideal temperature for the synthesis of L-asparaginase by many organisms was between 37 and $42{ }^{\circ} \mathrm{C}$, which falls within the range of 35 to $50{ }^{\circ} \mathrm{C}$ recorded by many other researchers in their investigations. E. coli exhibited good production of $\mathrm{L}$-asparaginase at a temperature of $37{ }^{\circ} \mathrm{C}$ [28]. According to Erva et al. [22], the best temperature for the enhanced production of L-asparaginase by Bacillus subtilis VUVD001 was $49.9^{\circ} \mathrm{C}$.

Another physical factor that has a significant role in microbial growth and metabolite production is $\mathrm{pH}$. Acinetobacter baumannii ZAS1 showed its maximum L-asparaginase activity of $19.201 \pm 0.2 \mathrm{U} / \mathrm{mL}$ at $\mathrm{pH} 7$ and lower enzyme activity below and above $\mathrm{pH} 7$. Similarly, Ghosh et al. [10] obtained maximum L-asparaginase activity at a neutral pH of 7.4 for Serratia marcescens.

Agitation speed is a critical parameter that influences enzyme production by providing adequate mixing, increasing the oxygen transfer, and maintaining the 
Table 7 Validation of the model

\begin{tabular}{llllllll}
\hline Run & L-asparagine & Peptone & Glucose & & $\mathbf{N a}_{\mathbf{2}} \mathrm{HPO}_{\mathbf{4}}$ & & \multicolumn{2}{l}{ L-asparaginase activity $(\mathbf{U} / \mathbf{m L})$} & Residual \\
\cline { 5 - 7 } & $\mathbf{g} / \mathbf{l}$ & $\mathbf{g} / \mathbf{l}$ & $\mathbf{g} / \mathbf{l}$ & $\mathbf{g} / \mathbf{l}$ & Observed & Predicted \\
\hline 1 & 11.80 & 6.30 & 0.98 & 7.66 & 45.2431 & 44.6565 & 0.59 \\
2 & 11.50 & 5.30 & 1.32 & 7.54 & 45.5903 & 45.0408 & 0.55 \\
3 & 11.02 & 4.57 & 1.19 & 7.44 & 43.8542 & 44.5338 & -0.68 \\
\hline
\end{tabular}

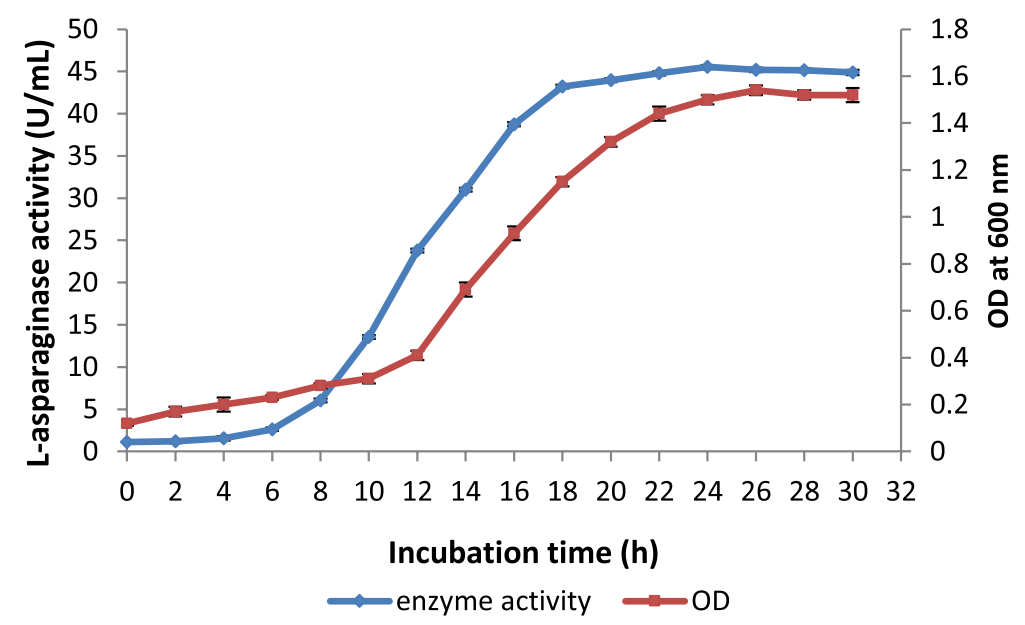

Fig. 4 L-asparaginase production profile and growth curve of Acinetobacter baumannii ZAS1

homogeneous chemical and physical conditions in the medium [29]. The endophyte Acinetobacter baumannii ZAS1 showed maximum L-asparaginase production of $18.854 \pm 0.6 \mathrm{U} / \mathrm{mL}$ with an agitation speed of $150 \mathrm{rpm}$. Similarly, the bacteria E. coli ATCC 11303 [30] exhibited maximum L-asparaginase activity when incubated under an agitation speed of $150 \mathrm{rpm}$. A slightly higher agitation speed of $200 \mathrm{rpm}$ was found to be effective for producing L-asparaginase by Bacillus subtilis VUVD001 [22]. There was a report on a very high agitation speed of $500 \mathrm{rpm}$ for better production of $\mathrm{L}$-asparaginase by Erwinia aroideae [31]. It shows that optimum agitation speed varies among microbes.

The preliminary screening of different nitrogen, carbon, and ion sources through the OFAT method revealed that the supplementation of these ingredients considerably enhanced enzyme production. Carbon sources are essential components in constructing cellular materials and are also used as energy sources [32]. Several earlier studies revealed the importance of additional nitrogen, carbon, and ion sources in the augmented production of this enzyme [33]. The organism Enterobacter aerogenes showed maximum $\mathrm{L}$-asparaginase production in the presence of diammonium hydrogen phosphate and sodium citrate as nitrogen and carbon sources, respectively [34].
Pseudomonas resinovorans IGS-131 exhibited maximum production of L-asparaginase when $\mathrm{Na}_{2} \mathrm{HPO}_{4}, \mathrm{KH}_{2} \mathrm{PO}_{4}$, and $\mathrm{NaCl}$ were used as ion sources [35].

In the present study, screening of different media ingredients for the maximal production of $\mathrm{L}$-asparaginase by Acinetobacter baumannii ZAS1 was performed through PBD experiments. PBD was successfully used in previous studies to optimize media components for maximum L-asparaginase activity by Bacillus sp. GH5 [36] as well as enhanced production of glucoamylase by Humicola grisea MTCC 352 [37]. This experiment identified four ingredients, namely, L-asparagine, peptone, glucose, and $\mathrm{Na}_{2} \mathrm{HPO}_{4}$, as statistically significant using PlackettBurman design. The $R^{2}$ score in this study was 0.9445 , indicating that the model was good. Furthermore, the adjusted $R^{2}$ of 0.9042 was relatively high, showing that the model was highly significant. This model had a higher predicted $R^{2}(0.8166)$ value, indicating that it can predict the value of $\mathrm{L}$-asparaginase synthesis in the range of parameters utilized. Similar work has been reported in PBD experiment of Streptomyces rochei in the improved production of L-asparaginase [38].

In this study, L-asparagine showed a significant effect with $(p=0)$ on the production of L-asparaginase. In previous investigations, the amino acid L-asparagine 
was discovered as a natural substrate for synthesizing L-asparaginase [39]. The second variable chosen via PBD, namely peptone, contains various amino acids and short peptides that may act as additional stimulatory components for the production of the $\mathrm{L}$-asparaginase enzyme. Some previous works also reported the importance of peptone as an additional supplement for the best production of L-asparaginase by Streptomyces ginsengisoli [40]. In the present investigation, the carbon source glucose (simple sugar) was the third variable selected through PBD, which significantly affects the production of L-asparaginase. Reports were available to depict the importance of glucose in producing $\mathrm{L}$-asparaginase from different microbes [40]. Ions also play a crucial role in the metabolic process of all organisms, as it is essential for the formation of cell mass and acts as a cofactor for many biosynthetic enzymes to catalyze the necessary reactions [41]. Borkotaky and Bezbaurauh [42] have reported no inhibitory effect on the production of L-asparaginase by $10 \mathrm{mmol} / \mathrm{L}$ metal ions such as $\mathrm{Na}^{2+}, \mathrm{K}^{+}, \mathrm{Mg}^{2+}, \mathrm{Zn}^{2+}$, $\mathrm{Ca}^{2+}, \mathrm{Co}^{2+}, \mathrm{Ba}^{2+}$, and $\mathrm{Ni}^{2+}$. In this study, $\mathrm{Na}_{2} \mathrm{HPO}_{4}$ had been selected as the significant ion source for the improved production of $\mathrm{L}$-asparaginase enzyme. The optimization studies of Bacillus sp. GH5 through statistical analyses had revealed the significance of $\mathrm{Na}_{2} \mathrm{HPO}_{4}$ in the production of L-asparaginase [36].

Further optimizations of these selected factors for maximizing the L-asparaginase activity were performed through the CCD of RSM. In an analysis of variance (ANOVA), the closer the $R^{2}$ number is to 1.0 , the stronger the model is and the better it predicts the reaction of the system [43]. In the current study, we obtained an $R^{2}$ value near 1.0, indicating the model's strength. The ANOVA results of this study revealed the importance of a well-designed experimental model that accurately depicts the relationship of the variables in the enhanced L-asparaginase activity. The higher $F$ value (165.72) in the ANOVA findings implies that the second-order model equation derived was significant. Lack of fit $F$ value can also be used to confirm the importance of the second-order model. Lack of fit has a lower $F$ value (0.67) than the other variables, with larger $F$ values. The non-significant lack of fit value suggests that the model was significant [44]. There is a previous report on the high $F$ value (43.04) of the model and lower $F$ value (2.98) of lack of fit that suggested the significance of the model in the optimization of glucoamylase production by Humicola grisea MTCC 352 [45].

The interactive effect of the above described four variables on the L-asparaginase output by Acinetobacter baumannii ZAS1 was studied using this method. Response surface plots were used to illustrate the function of two variables at a time while keeping all other variables constant. As a result, these graphs were more helpful in comprehending the interaction effects of these two variables [46].

In the validation of the present study, a 2.41-fold increase in L-asparaginase activity $(18.85 \pm 0.2 \mathrm{U} /$ $\mathrm{mL}$ to $45.59 \pm 0.36 \mathrm{U} / \mathrm{mL}$ ) by Acinetobacter baumannii ZAS1 has been obtained with optimized medium $(11.50 \mathrm{~g} / \mathrm{l} \mathrm{L}$-asparagine, $5.30 \mathrm{~g} / \mathrm{l}$ peptone, $1.32 \mathrm{~g} / \mathrm{l}$ glucose, and $7.54 \mathrm{~g} / \mathrm{l} \mathrm{Na}_{2} \mathrm{HPO}_{4}$ ). Similarly, Kenari et al. [30], in their study, revealed that the highest L-asparaginase activity by E. coli ATCC 11303 was observed by optimizing the media ingredients through RSM.

The growth curve study revealed that the organism's growth and the production of L-asparaginase were associated. The most activity was seen in the late log phase, and after that, it steadily declined. Similar results were reported by Shirazian et al. [47]. According to their study, the halophilic Bacillus strain gA5 revealed the correlation between growth and L-asparaginase production.

\section{Conclusions}

Based on the results of this experiment, we concluded that the endophyte Acinetobacter baumannii ZAS1 is the best source of the L-asparaginase enzyme. The enzyme production with this strain was enhanced by optimizing process parameters through statistical methods PBD and CCD of RSM. We were able to find the ideal parameters for obtaining the best L-asparaginase production $(45.59 \pm 0.36 \mathrm{U} / \mathrm{mL})$ using these methods. Statistical optimization showed a 2.41-fold increase in enzyme production compared to unoptimized media. Finally, this research had demonstrated that experimental designs gave a quick and meaningful approach to improve productivity of $\mathrm{L}$-asparaginase. The findings showed that Acinetobacter baumannii ZAS1 can produce large quantities of L-asparaginase with minimal medium components, implying that its usage in industries could result in significant cost reductions on an industrial scale.

\section{Abbreviations}

ALL: Acute lymphoblastic leukemia; ANOVA: Analysis of variance; CCD: Central composite design; OFAT: One factor at a time; PBD: Plackett-Burman design; RSM: Response surface methodology; UGC: University Grants Commission.

\section{Supplementary Information}

The online version contains supplementary material available at https://doi. org/10.1186/s43141-022-00309-4.

Additional file 1: Supplementary Figure 1. Normal plot of residuals and other plots of CCD. 


\begin{abstract}
Acknowledgements
The project was funded by Junior Research Fellowship provided by UGC (321453), and the work was carried out at the Department of Life Sciences, University of Calicut. The authors, therefore, acknowledge the UGC for financial support and the Dept. of Life Sciences for providing the necessary facilities. We also thank our colleagues who have supported us in every way towards the completion of this work.
\end{abstract}

\section{Authors' contributions}

The present work was carried out in collaboration with all four authors. Author KFZ and DS designed and supervised the study. Author KNA managed the literature search and performed the experiment, data analysis, and wrote the first draft of the manuscript. ABR helped in performing the data analysis and writing the manuscript. Authors KFZ and DS edited and proofread the final manuscript. All four authors read and approved the final manuscript.

\section{Funding}

The project was funded by a UGC Junior Research Fellowship (321453).

\section{Availability of data and materials}

All data generated or analyzed during this study are included in this article.

\section{Declarations}

Ethics approval and consent to participate

Not applicable

\section{Consent for publication}

Not applicable

\section{Competing interests}

The authors declare that they have no competing interests.

Received: 23 July 2021 Accepted: 23 January 2022

Published online: 09 February 2022

\section{References}

1. Anishkin A, Vanegas JM, Rogers DM, Lorenzi PL, Chan WK, Purwaha P et al (2015) Catalytic role of the substrate defines specificity of therapeutic L-asparaginase. J Mol Biol 427:2867-2885. https://doi.org/10.1016/j.jmb. 2015.06.017

2. Cooney DA, Handschumacher RE (1970) L-asparaginase and L-asparagine metabolism. Annu Rev Pharmacol 10:421-440. https://doi.org/10.1146/ annurev.pa.10.040170.002225

3. Ficai A, Grumezescu AM (2017) Nanostructures for cancer therapy. Elsevier, Amsterdam, Netherlands

4. Blake MK, Carr BJ, Mauldin GE (2016) Hypersensitivity reactions associated with L-asparaginase administration in 142 dogs and 68 cats with lymphoid malignancies: 2007-2012. Can Vet J 57:176-182

5. dos Santos AC, Land MGP, da Silva NP, Santos KO, Lima-Dellamora ED (2017) Reactions related to asparaginase infusion in a 10-year retrospective cohort. Rev Bras Hematol E Hemoter 39:337-342. https://doi.org/10 1016/j.bjhh.2017.08.002

6. Offman MN, Krol M, Patel N, Krishnan S, Liu J, Saha V et al (2011) Rational engineering of L-asparaginase reveals importance of dual activity for cancer cell toxicity. Blood 117:1614-1621. https://doi.org/10.1182/ blood-2010-07-298422

7. Fonseca MHG, da Silva Fiúza T, de Morais SB, de Souzade ACBT, Trevizani R (2021) Circumventing the side effects of L-asparaginase. Biomed Pharmacother 139:111616. https://doi.org/10.1016/j.biopha.2021.111616

8. Pieters R, Hunger SP, Boos J, Rizzari C, Silverman L, Baruchel A et al (2011) L-asparaginase treatment in acute lymphoblastic leukemia: a focus on Erwinia asparaginase. Cancer 117:238-249. https://doi.org/10.1002/cncr 25489

9. Thenmozhi C, Sankar R, Karuppiah V, Sampathkumar P (2011) L-asparaginase production by mangrove derived Bacillus cereus MAB5: Optimization by response surface methodology. Asian Pac J Trop Med 4:486-491. https://doi.org/10.1016/S1995-7645(11)60132-6
10. Ghosh S, Murthy S, Govindasamy S, Chandrasekaran M (2013) Optimization of L-asparaginase production by Serratia marcescens (NCIM 2919) under solid state fermentation using coconut oil cake. Sustain Chem Process 1:9. https://doi.org/10.1186/2043-7129-1-9

11. Patel P, Gosai HB, Panseriya H, Dave B (2021) Development of process and data centric inference system for enhanced production of L-asparaginase from halotolerant Bacillus licheniformis PPD37, In Review. https://doi.org/ 10.21203/rs.3.rs-651645/v1

12. Singhal B, Swaroop K (2013) Optimization of culture variables for the production of L-asparaginase from Pectobacterium carotovorum. Afr J Biotechnol 12:6959-6967. https://doi.org/10.5897/AJB12.2624

13. Baskar G, Supria Sree N (2020) Synthesis, characterization and anticancer activity of $\beta$-cyclodextrin-Asparaginase nanobiocomposite on prostate and lymphoma cancer cells. J Drug Deliv Sci Technol 55:101417. https:// doi.org/10.1016/j.jddst.2019.101417

14. Schulz B, Boyle C, Draeger S, Römmert A-K, Krohn K (2002) Endophytic fungi: a source of novel biologically active secondary metabolites. Mycol Res 106:996-1004. https://doi.org/10.1017/S0953756202006342

15. Strobel GA (2003) Endophytes as sources of bioactive products. Microbes Infect 5:535-544. https://doi.org/10.1016/S1286-4579(03)00073-X

16. Khan YM, Munir H, Anwar Z (2019) Optimization of process variables for enhanced production of urease by indigenous Aspergillus niger strains through response surface methodology. Biocatal Agric Biotechnol 20:101202. https://doi.org/10.1016/j.bcab.2019.101202

17. Kavuthodi B, Sebastian D (2018) Biotechnological valorization of pineapple stem for pectinase production by Bacillus subtilis BKDS1: Media formulation and statistical optimization for submerged fermentation. Biocatal Agric Biotechnol 16:715-722. https://doi.org/10.1016/j.bcab. 2018.05.003

18. Abhini KN, Fathimathu Zuhara K (2018) Isolation screening and identification of bacterial endophytes from medicinal plants as a potential source of L-asparaginase enzyme. J Chem Pharm Sci 11:73-76. https://doi.org/ 10.30558/jchps.20181101014

19. Nucleo E, Steffanoni L, Fugazza G, Migliavacca R, Giacobone E, Navarra A et al (2009) Growth in glucose-based medium and exposure to subinhibitory concentrations of imipenem induce biofilm formation in a multidrug-resistant clinical isolate of Acinetobacter baumannii. BMC Microbiol 9:270. https://doi.org/10.1186/1471-2180-9-270

20. Imada A, Igarasi S, Nakahama K, Isono M (1973) Asparaginase and glutaminase activities of micro-organisms. J Gen Microbiol 76:85-99. https:// doi.org/10.1099/00221287-76-1-85

21. Barrak N, Mannai R, Zaidi M, Kechida M, Helal AN (2016) Experimental design approach with response surface methodology for removal of indigo dye by electrocoagulation. J Geosci Environ Prot 04:50-61. https:// doi.org/10.4236/gep.2016.411006

22. Erva RR, Goswami AN, Suman P, Vedanabhatla R, Rajulapati SB (2017) Optimization of L-asparaginase production from novel Enterobacter sp., by submerged fermentation using response surface methodology. Prep Biochem Biotechnol 47:219-228. https://doi.org/10.1080/10826068.2016.1201683

23. Saeed AM, El-Shatoury EH, Sayed HAE (2021) Statistical factorial designs for optimum production of thermostable a-amylase by the degradative bacterium Parageobacillus thermoglucosidasius Pharon 1 isolated from Sinai. Egypt J Genet Eng Biotechnol 19:24. https://doi.org/10.1186/ s43141-021-00123-4

24. Sreena CP, Sebastian D (2018) Augmented cellulase production by Bacillus subtilis strain MU S1 using different statistical experimental designs. J Genet Eng Biotechnol 16:9-16. https://doi.org/10.1016/j.jgeb.2017.12.005

25. Dayal MS, Goswami N, Sahai A, Jain V, Mathur G, Mathur A (2013) Effect of media components on cell growth and bacterial cellulose production from Acetobacter aceti MTCC 2623. Carbohydr Polym 94:12-16. https:// doi.org/10.1016/j.carbpol.2013.01.018

26. Banerjee R, Bhattacharyya BC (1992) Extracellular alkaline protease of newly isolatedRhizopus oryzae. Biotechnol Lett 14:301-304. https://doi. org/10.1007/BF01022328

27. Rahman RNZA, Geok LP, Basri M, Salleh AB (2005) Physical factors affecting the production of organic solvent-tolerant protease by Pseudomonas aeruginosa strain K. Bioresour Technol 96:429-436. https://doi.org/10. 1016/j.biortech.2004.06.012

28. Cachumba JJM, Antunes FAF, Peres GFD, Brumano LP, Santos JCD, Da Silva SS (2016) Current applications and different approaches for microbial 
I-asparaginase production. Braz J Microbiol 47:77-85. https://doi.org/10. 1016/j.bjm.2016.10.004

29. Mostafa Y, Alrumman S, Alamri S, Hashem M, Al-izran K, Alfaifi M et al (2019) Enhanced production of glutaminase-free l-asparaginase by marine Bacillus velezensis and cytotoxic activity against breast cancer cell lines. Electron J Biotechnol 42:6-15. https://doi.org/10.1016/j.ejbt.2019. 10.001

30. Kenari SLD, Alemzadeh I, Maghsodi V (2011) Production of I-asparaginase from Escherichia coli ATCC 11303: optimization by response surface methodology. Food Bioprod Process 89:315-321. https://doi.org/10. 1016/j.fbp.2010.11.002

31. Liu FS, Zajic JE (1973) Effect of oxygen-transfer rate on production of L-asparaginase by Erwinia aroideae. Can J Microbiol 19:1153-1158. https://doi.org/10.1139/m73-183

32. Masurekar P (2009) Antibiotic production. In: Encycl Microbiol. Elsevier, pp 174-190. https://doi.org/10.1016/B978-012373944-5.00032-8

33. El-Naggar NE-A, Moawad H, El-Shweihy NM, El-Ewasy SM, Elsehemy IA, Abdelwahed NAM (2019) Process development for scale-up production of a therapeutic L-asparaginase by Streptomyces brollosae NEAE-115 from shake flasks to bioreactor. Sci Rep 9:13571. https://doi.org/10.1038/ s41598-019-49709-6

34. Mukherjee J, Majumdar S, Scheper T (2000) Studies on nutritional and oxygen requirements for production of $\mathrm{L}$ - asparaginase by Enterobacter aerogenes. Appl Microbiol Biotechnol 53:180-184. https://doi.org/10. $1007 / \mathrm{s} 002530050006$

35. Mihooliya KN, Nandal J, Kumari A, Nanda S, Verma H, Sahoo DK (2020) Studies on efficient production of a novel l-asparaginase by a newly isolated Pseudomonas resinovorans IGS-131 and its heterologous expression in Escherichia coli. 3 Biotech 10:148. https://doi.org/10.1007/ s13205-020-2135-4

36. Gholamian S, Gholamian S, Nazemi A, Miri Nargesi M (2013) Optimization of culture media for L-asparaginase production by newly isolated bacteria, Bacillus sp. GH5. Microbiology 82:856-863. https://doi.org/10. 1134/S0026261714010032

37. Ramesh V, Ramachandra Murty V (2014) Sequential statistical optimization of media components for the production of glucoamylase by thermophilic fungus Humicola grisea MTCC 352. Enzyme Res 2014:1-9. https://doi.org/10.1155/2014/317940

38. El-Naggar NE-A, El-Shweihy NM (2020) Bioprocess development for L-asparaginase production by Streptomyces rochei, purification and invitro efficacy against various human carcinoma cell lines. Sci Rep 10:7942. https://doi.org/10.1038/s41598-020-64052-x

39. Aghaiypour K, Wlodawer A, Lubkowski J (2001) Structural basis for the activity and substrate specificity of Erwinia chrysanthemi L-asparaginase. Biochemistry 40:5655-5664. https://doi.org/10.1021/bi0029595

40. Deshpande N, Choubey P, Agashe M $(2014,2014)$ Studies on optimization of growth parameters for L-asparaginase production by streptomyces ginsengisoli. Sci World J. https://doi.org/10.1155/2014/895167

41. Hutner SH, Provasoli L, Schatz A, Haskins CP (1950) Some approaches to the study of the role of metals in the metabolism of microorganisms. Proc Am Philos Soc 94:152-170

42. Borkotaky B, Bezbaruah RL (2002) Production and properties of asparaginase from a new Erwinia sp. Folia Microbiol (Praha) 47:473-476. https:// doi.org/10.1007/BF02818783

43. Doddapaneni KK, Tatineni R, Potumarthi R, Mangamoori LN (2007) Optimization of media constituents through response surface methodology for improved production of alkaline proteases by Serratia rubidaea. J Chem Technol Biotechnol 82:721-729. https://doi.org/10.1002/jctb.1714

44. Montgomery DC, Myers RH, Carter WH, Vining GG (2005) The hierarchy principle in designed industrial experiments. Qual Reliab Eng Int 21:197-201. https://doi.org/10.1002/qre.615

45. Department of Chemical Engineering, Manipal Institute of Technology, Manipal Academy of Higher Education, Manipal 576104, Karnataka, India, Ramesh V, Murty VR, and Department of Biotechnology, Manipal Institute of Technology, Manipal Academy of Higher Education, Manipal 576104, Karnataka, India (2019) Optimization of glucoamylase production by humicola grisea MTCC 352 in solid state fermentation. Chiang Mai Univ. J. Nat. Sci. 18:. https://doi.org/10.12982/CMUJNS.2019.0018.

46. Bibi N, Ali S, Tabassum R (2016) Statistical optimization of pectinase biosynthesis from orange peel by Bacillus licheniformis using submerged fermentation. Waste Biomass Valorization 7:467-481. https://doi.org/10. 1007/s12649-015-9470-4

47. Shirazian P, Asad S, Amoozegar MA (2016) The potential of halophilic and halotolerant bacteria for the production of antineoplastic enzymes: L-asparaginase and L-glutaminase. EXCLI J 15:268 ISSN 1611-2156. https://doi.org/10.17179/EXCLI2016-146

\section{Publisher's Note}

Springer Nature remains neutral with regard to jurisdictional claims in published maps and institutional affiliations.

\section{Submit your manuscript to a SpringerOpen ${ }^{\circ}$ journal and benefit from:}

- Convenient online submission

- Rigorous peer review

- Open access: articles freely available online

- High visibility within the field

- Retaining the copyright to your article

Submit your next manuscript at $\boldsymbol{\nabla}$ springeropen.com 